\title{
The Multiple Waves of the African Academic Diaspora's Engagement with African Universities
}

\author{
Ibrahim O Oanda and Mark M Obonyo
}

\begin{abstract}
This article analyses the various historical phases in the evolution of the African academic diaspora's engagement to support the development of higher education in Africa. It examines the drivers and motivation for such engagement and its implications for higher education development on the continent. The data were derived from a critical review of secondary sources, supplemented by primary observations by one of the authors who is engaged in a programme that supports diaspora academics to travel to African universities for engagement, as part of the third wave. The analysis of the secondary material shows that while the first wave of engagement was driven by a strong sense of Pan-Africanism at the global level and laid the foundation for the establishment of universities across the continent, the second wave became trapped in Cold War rivalries that limited engagement and drove more academics from African universities into exile, mainly in Europe and North America, thus swelling the ranks of diaspora academics. The third wave has been caught up in a similar situation. While the forces of globalisation and internationalisation that are driving this wave of diaspora engagement have the potential to support African universities to achieve international standards, they can equally undermine and mute the desire for higher education decolonisation. The article recommends that African countries and higher education institutions should play a central role in designing the broad policy context that drives engagement and that the activities undertaken by African diaspora academics should align with national higher education priorities.
\end{abstract}

About the AUthors: ibRAHIM O OANDA, CODESRIA, Dakar, Senegal. Email: ibrahimoanda@gmail.com. MARK M OBONYO, Kenyatta University, Kenya. Email: markobonyo@gmail.com 
Key words: African, Africanisation, higher education, African academic diaspora, engagement, internationalisation, decolonisation

Cet article analyse les différentes phases historiques de l'évolution des engagements de la diaspora académique africaine pour soutenir le développement de l'enseignement supérieur en Afrique. Il examine les raisons motrices et la motivation d'un tel engagement et ses implications pour le développement de l'enseignement supérieur sur le continent. Les données ont été dérivées d'un examen critique de matériel obtenu de sources secondaires, complété par les observations primaires de l'un des auteurs qui est engagé dans un programme qui aide les universitaires de la diaspora à se rendre, dans le cadre de la troisième vague, dans les universités africaines pour s'engager dans leurs activités. L'analyse du matériel secondaire montre que si la première vague d'engagement a été motivée par un fort sentiment de panafricanisme au niveau mondial et a jeté les bases de la création d'universités à travers le continent, la deuxième vague s'est retrouvée piégée dans les rivalités de la guerre froide lesquelles rivalités ont limité ces engagement et conduit plus d'universitaires des universités africaines à l'exil, principalement en Europe et en Amérique du Nord, gonflant ainsi les rangs des universitaires de la diaspora. La troisième vague a été prise dans une situation similaire. Les forces de la mondialisation et de l'internationalisation qui sont à l'origine de cette vague d'engagement de la diaspora ont sans doute le potentiel d'aider les universités africaines à atteindre les normes internationales, mais il faut noter qu'elles peuvent saper et étouffer le désir de décolonisation de l'enseignement supérieur. L'article recommande que les pays africains et les établissements d'enseignement supérieur jouent un rôle central dans la conception du contexte politique général qui motive l'engagement et que les activités entreprises par les universitaires de la diaspora africaine doivent s'aligner sur les priorités nationales de l'enseignement supérieur.

Mots clés: Afrique, africanisation, enseignement supérieur, diaspora académique africaine, engagement, internationalisation, décolonisation

\section{Introduction}

Interest in soliciting support from the African academic diaspora to enhance and sustain African universities' capacities has grown since the African Union's (AU) African Diaspora Summit in 2012, and the subsequent creation of the Diaspora Division within the AU Commission. However, these efforts are not new. During the colonial period the African diaspora committed itself to the quest to establish higher education institutions (HEIs) on the continent. This relationship has evolved over time, often reflecting individual and institutional interests on the part of both Africa and countries hosting the African diaspora. Incentives for the African academic diaspora to organise as individuals or groups to connect to institutions on the continent have been enabled and sustained through different dynamics. This article traces the African academic diaspora's engagement with higher education in Africa through three waves. While the first and second waves were driven by the African academic diaspora's strong sense of identity with the continent through higher education, the third wave is emerging in a more complex context. Internationalisation, which has blurred the boundaries between global and national higher education contexts often means that the academic diaspora navigates a thin line between engagement in promoting the interests of higher education institutions in Africa, as expressed through demands for decolonisation and Africanisation of higher education, and those that potentially erode the capacity of African institutions to achieve these aspirations.

\section{The African Academic Diaspora and African Higher Education: The First Wave}

The first wave of the African academic diaspora's support for higher education in Africa spanned the period from the mid-I $9^{\text {th }}$ century (I840s) to the inter-war period of the I920s and I930s. The players were descendants of the original African diaspora of slavery who affiliated with missionary groups in Britain and the United States (US), especially the Protestant Episcopal Church of the US and the Church Missionary Society (Sherman, I990). While African HEIs and policymakers' consciousness of the African academic diaspora's potential to capacitate African universities is recent, during the first wave, this diaspora played a major role in efforts to establish universities on the continent and influenced the shape they took. Against the backdrop of colonial governments' reluctance to establish HEIs for Africans (Adick, I989), African diaspora intellectuals such as Edward Blyden and James Africanus Beate Horton pioneered the idea of a secular West African university managed by Africans to anchor the consolidation of African cultural nationalism, echoing current demands for higher education decolonisation across the continent (Frenkel, I974; Hargreaves, I973; Lynch, I965). Blyden and Horton's efforts were motivated by two imperatives. The first was to show that Africans could achieve equal standards in educational and cultural endeavours, thus challenging European paternalistic and racist supremacy. Secondly, the establishment of African universities was regarded as a strategy to modernise Africa technologically, economically and socio-culturally (Adick, I989; Lynch i965).

In a sense, Blyden and Horton helped to expose the contradiction in European colonial policy that promised Africans 'civilization' while at the 
same time denying them institutions such as universities that would be critical to attaining such (Adick, I989). Colonial governments were not open to demands for public HEIs for Africans, preferring to encourage initiatives supported by missionaries and local intellectuals. However, these efforts fell short of the type of HEI envisaged by Blyden and Horton (Lynch, I965). Hayford, a close friend of Blyden, recommended the establishment of a secular West African university that would be a "seat of learning so renowned and attractive that students from the United States, the West Indies, Sierra Leone, and Liberia, as well as from Lagos and the Bambia, would flock to it" (Hayford, I969, pp. I96-197). Minimal but catalytic success was achieved in 1876 when the British colonial government allowed the affiliation of Fourah Bay College in Sierra Leone, founded by the Church Missionary Society in I827, with the English University of Durham (Frenkel, I976; Adick, I989). Arguably, the African intellectual diaspora's most important contribution during this period was that their involvement was part of a broad programme of decolonisation, Pan-Africanism and nationalism. As Zeleza (2006) notes, their initial efforts were crucial in the reconstruction of Africa as an idea and object of study, Africans as academics, and Pan-Africanism as a project.

The historical African diaspora also helped shape the future of higher education in Africa in two other respects. In the first instance, as African demands for higher education grew, especially the ambition for the establishment of a university along the lines of that called for by the National Congress of West Africa, the historical diaspora in the US influenced the direction of higher education. The promotion of the Hampton-Tuskegee experiment in Africa by Booker T. Washington and Aggrey James Emman Kwegyir did much to influence British colonial policy on higher education in its African colonies (Steiner-Khamsi and Quist, 2000). It was due to their influence that Achimota College, in the then Gold Coast (Ghana) was established as the first secular British educational institution in colonial Africa to implement the Hampton-Tuskegee model of industrial education (Steiner-Khamsi and Quest, 2000). Aggrey would later serve on the Phelps-Stokes Commission on Education to Africa, that among other recommendations, led to increased colonial investment in African education and laid the foundation for the expansion of educational opportunities for girls and higher education more generally. Beyond the push for HamptonTuskegee type higher education for Africans in Africa, a position strongly articulated by Aggrey, the commission led to greater British involvement in the provision of education for Africans for fear of the emerging American influence in providing higher education, especially in West Africa, as articulated in the Phelps-Stokes Educational Report of I924 (Nwauwa, I993). The subsequent establishment of colleges at Achimota, the Yaba Higher College in Nigeria and Makerere in Uganda thus had as much to do with this fear as with the African quest for higher education which was partly influenced by the African historical diaspora's involvement, especially in West Africa. With respect to Makerere College, the report was clear that it might be the seed from which a future university would emerge.

A significant number of African student movements emerged in Europe and North America, especially during the interwar period of the I920s and I930s. While they largely focused on student welfare, a number pursued broad political objectives similar to the nationalist movements of the time, advocating for cultural nationalism in Africa through education (Boahen, I994). One of the most prominent was the West African Students' Union (WASU), which was founded in London in I924. It maintained pressure on the Colonial Office, making use of its contacts to argue for education in West Africa to standards recognised beyond the region (Boahen, I994). Pressure from these student movements added impetus to the growth in higher education facilities in Africa, though with much reluctance on the part of colonial governments.

Assessing the imprints left by this first generation of diaspora engagement provides a better starting point to capture the contribution of the African diaspora to higher education in Africa. The historical diaspora's participation was self-driven by the need to identify with the continent of their origin and to contribute to its development in ways that would elevate African culture in counter-opposition to European culture. Besides putting pressure on colonial governments to establish university level institutions for Africans, they drew attention to the kind of higher education that Africans needed to develop in the spirit of Pan-Africanism. For example, Edward Blyden advocated for a liberal kind of higher education rooted in an African cultural and intellectual climate, with content that reflected African achievements in order to free the African from despotic Europeanising influences (Frankel, I974; Ndlovu-Gatsheni, 20I7). On the other hand, Booker T. Washington and those aligned to his thinking, such as Aggrey James Emman Kwegyir advocated for a "transplanted" kind of higher education along the lines of what had been offered to Negros in America. Blyden's advocacy for a liberal education was seen in the emergence of university colleges such as Makerere in East Africa, which started as a technical college, but went on to embrace a liberal curriculum. The Booker T. Washington-Aggrey line of thinking that advocated for education at all levels along the lines of adaptation, resulted in the establishment of colleges such as Achimota, and later, following the first World War, the Royal Technical College (now the University of Nairobi) in East Africa.

The divergent positions taken by the historical diaspora in their support for higher education in Africa continue, with arguments for liberal human- 
ities and social science higher education and one tending more towards science and technology as a solution to Africa's problems, such as relevance and employability. As the African academic diaspora re-emerges as a force to build capacity in African higher education, the following sections discuss how their engagement mirrors these original concerns and contradictions.

The importance of the first wave of African diaspora engagement is that it laid the foundation for the shape of HEIs established on the continent in the period after the second World War. The first wave of engagement was instrumental in the setting up of various committees during the inter-war period to explore the possibility of establishing universities in the colonies. For example, the Asquith Commission, which was appointed in I943, and whose report was published in I945, became the blueprint for the establishment of universities in British colonies (Sherman, I990).

\section{The Second Wave: Establishment of National Universities and the Era of Developmentalism}

The second wave of African diaspora engagement was led by descendants of the first wave and Africans who had studied in Europe and the US during the inter-war period. This wave covered the period from the I950s, when Ghana gained independence, until i9 80 and was characterised by African nationalism and Pan-Africanism, coupled with the euphoria of independence and the imperative of decolonising knowledge (Zeleza, 2009). Two forces drove the second wave. The first was Pan-Africanism that motivated intellectuals from the African diaspora to return to the continent and to lay the foundations for the intellectual decolonisation of higher education in the nascent universities. African academics associated with the diaspora of slavery in the US, the UK and the Caribbean made up most of the expatriate faculty in the nascent universities and research centres between I960 and I980 (Court and Mbalibulha, 2013). The pervasiveness of the Pan-African spirit during this period also saw various African governments awarding scholarships to students from other African countries to attend their newly established universities, a trend that contributed to the creation and circulation of an academic diaspora within the continent (Marah, I987).

Some of these academics, such as Walter Rodney, were ideologically driven to return to Africa by the inspiration they drew from their participation in the Fifth Pan-African Conference of I945 (Bly, I985). This diaspora became part of efforts to decolonise the curriculum in the nascent African universities and to establish renowned centres of teaching and research excellence in these institutions. For example, Rodney was among the progressive academics at the University of Dar es Salaam in Tanzania that aimed to build East African institutions of higher learning that would create a new cadre of African academics to anchor the spirit of African liberation which was still in process (Campbell, I986). Besides his groundbreaking work on, "How Europe Underdeveloped Africa,", he contributed to the establishment of a particular intellectual orientation which came to be associated with the Dar es Salaam School of African History (Campbell, I986; Bly, I985). Most of Rodney's intellectual efforts were expended towards decolonising African and diaspora societies and confronting ideological narratives of African history and political economy.

In Uganda, the Makerere Institute of Social Research (MISR) benefitted from the scholarship of diaspora academics such as Archie Mafeje whose work contributed to a shift in the discourse on African people by African scholars by rejecting the western disciplinary canon of 'tribe' as the ultimate African condition, shaping social science debates for decades (Mbalibulha, 20I3). In Nigeria, diaspora academics were instrumental in breathing life into the Ibadan School of History, where they worked on an even footing with their British counterparts (Coquery-Vidrovitch, 2013). The School made an immense contribution to the renewal of scholarship in African historiography.

Equally significant were the African academic diaspora's efforts during the period before and immediately after independence to decolonise the production of knowledge about Africa. In so doing, they contributed to the deconstruction of colonial misrepresentations of Africa in the metropolitan countries. Since knowledge on and about Africa was closely linked to the colonial project with its Eurocentric assumptions and prejudices, African diaspora academics were critical in confronting the intellectual balkanisation of Africa and intellectual dependence in the production of social knowledge on Africa (Ogot, 20I1.; Zeleza, 2009). Mention should also be made of the contribution of African diaspora academics in Europe and the Caribbean to the establishment of infrastructure for the dissemination of knowledge about Africa in Europe. For example, the periodical, Présence Africaine was founded in Paris in I947 by a dedicated African-Caribbean team under the leadership of the Senegalese Alioune Diop (Coquery-Vidrovitch, 2013) and served as an important avenue for African diaspora academics to publish their works in literature and history.

Thus, the second wave of African diaspora academics who returned to Africa were self-driven and were especially influenced by the 'back to Africa' message of the Fifth Pan-African Congress. Furthermore, whereas the first wave of African diaspora engagement was dominated by Afro-Americans, the second was dominated by black intellectuals from Europe and the Caribbean. Pan-African ideals also shaped the nature of their engagement, as they regarded decolonisation (at the time broadly expressed as Africanisation) of higher education as part of the political Pan-African project. 
Furthermore, since a number of higher education institutions were already established on the continent, the second wave of African diaspora academics engaged more with the question of curriculum content with the aim of promoting decolonisation of knowledge. The focus was on formulating a new philosophy of higher education informed by African histories, cultures, ideas, and aspirations as well as a fundamental redefinition of the role of the university (Ndlovu-Gatsheni, 20I7). In their quest for Africanisation of and through higher education, the African intellectual diaspora took on prominent roles as advisors to the African political leadership. Of note is the Caribbean intellectual diaspora's role in this regard; for example, George Padmore and Ras Makonnen who served as advisors to Kwame Nkrumah and Jomo Kenyatta, respectively (Ndlovu-Gatsheni, 20I9). The radical Pan-African movement that emanated from the Caribbean intellectual diaspora through the writings of people like Frantz Fanon, Aimé Césaire and Walter Rodney influenced intellectual debates on decolonisation and Africanisation of HEIs as academics contested the development paths the new nations were pursuing in the I960s and I970s (Austin, 20Iо). The importance of the intellectual diaspora, especially from the Caribbean, during this period was therefore to provide some ideological grounding to the quest for Africanisation of higher education and politics. It became critical in boosting the process of knowledge decolonisation in the new universities and establishing infrastructure for similar purposes in the metropolitan countries.

However, the second wave of academic diaspora engagement was not fully accommodated in the continent's nascent universities. During the I950s, the emergence of the Cold War and the Americans and Soviets' attempts to use higher education to spread their political and socio-economic models opened access to higher education opportunities for African students beyond the metropole countries. African students who gained access to these new destinations and came to constitute the second wave of diaspora academics were caught up in the new western scramble to control African elites that defined the Cold War (Burton, 2020). This was also witnessed in attempts to control curriculum content and development in the nascent universities in the name of "developmentalism" (Burton, 2020). Academic freedom and institutional autonomy were sacrificed at the altar of what the new African states and their western allies saw as the correct paths to development and modernisation, while academics who tended to align with the Soviet bloc were silenced (Mkandawire, 200I). The fate of Walter Rodney at the University of Dar es Salaam was a manifestation of Cold War rivalries. In a number of African countries, diaspora academics were denied entry into their countries and universities due to their intellectual persuasion. This situation persisted until the end of the Cold War in I990.

\section{The Third Wave: The Era of Internationalisation and the On-going Quest}

\section{for Decolonisation}

The third wave of diaspora engagement is different from the first and second in the sense that engagements have been shaped more by the demands of African institutions than the African diaspora's desire to engage in self-motivated efforts. The third wave has been bogged down by debate on how best to engage and extract value from the diaspora, how best to establish mutually beneficial academic relationships between diaspora academics and African-based scholars and institutions, and how such initiatives should be funded (Dell, 2020). One of the reasons for this lack of clarity on how engagements can be sustained is the nature of the diaspora academics who account for the third wave. A number of these academics were driven out of African universities by a combination of poor conditions and remuneration starting from the I980s, and political repression which constrained academic freedom. More recently, externally funded programmes have emerged that recruit and offer scholarships to the best performing high school graduates to undertake their bachelors and graduate degrees oversees. Most of these students will likely not return but will swell the ranks of the third wave of the African academic diaspora. As historical evidence shows, overseas scholarship programmes that aim to build capacity have had mixed results, as some beneficiaries do not return or return briefly and then relocate overseas.

The third wave is, however, similar to the preceding two in terms of the forces of globalisation, internationalisation and the quest for decolonisation of higher education in Africa that are still driving the nature of engagement. Globalisation-driven internationalisation is presented in the literature as a phenomenon that would help African HEIs to achieve 'international' standards while at the same time, manifesting all the features of historical patterns of dependency and deepening of the colonial architecture of higher education on the continent (Zeleza, 20I2a; Oanda, 2013). Certain imperatives of internationalisation, such as the desire by universities in Europe and North America to have an overseas presence and internationalise their curricula end up deepening and reproducing existing hierarchies in knowledge production and marginalising knowledge produced by institutions in less developed countries (Heilbron and Gingras, 20I8). Often, African diaspora academics coming to African universities do so as part of their home (Europe and North America) institutions' internationalisation policies and most likely on terms set by their home institutions. Consequently, some African diaspora academics wishing to engage with universities in Africa are likely to confront these contradictions, especially given African institutions' need to 'decolonise', while also aspiring to international status. As actors whose home institutions are based in developed countries, African 
diaspora academics in the third wave have to choose between academic interventions that erode local capacity and deepen the interests of foreign universities in African institutions, and those that lead to real autonomous capacity on the part of the latter.

Four drivers have tended to shape the nature and quality of the third wave African academic diaspora's engagements with scholars and academic institutions in Africa. These are the constitution of the academic diaspora, international and national support networks, sending institutions' internationalisation policies and the incentive structures in African host institutions.

In terms of the constitution of the academic diaspora, there is a tendency on both sides (within the diaspora community and African institutions) to individualise or collectivise the reasons for academics' relocation to constitute the diaspora. Those who relocated in search of better institutional infrastructure and remuneration are often seen by their counterparts in African institutions as individualistic and lacking the ability to fight on. Equally, such diaspora academics lament the lack of suitable conditions in African institutions to enable their meaningful engagement. Commonly cited issues include resource constraints, a lack of research and technology infrastructure, a shortage of well-trained faculty, inadequate facilities and equipment, and a lack of financial capital to support and sustain research (Ferede, n.d.). Ironically, these are the very constraints that African institutions look to the diaspora to help them overcome. However, this should not be a prerequisite for engagement. Setting conditions for sustainable engagement obviously reduces the vibrancy of such from institutional to individual level agreements between the diaspora scholar and a counterpart in the African host institution based on shared interests and academic engagement. Some studies have established that diaspora academics face homeland and institutional level challenges in their attempt to participate in knowledge transfer with African universities, including institutional bureaucracy, hierarchical structures, and inadequate facilities (Mohamoud, 2005).

On the other hand, the emergence of an African academic diaspora due to political repression at home has often led to the formation of organised diaspora groups. This has been true of the Ethiopian academic diaspora in the US and Europe that has formed various organisations to address economic and political marginalisation back home through specific interventions in the education sector (Ong'ayo, 20I4).

Hence, while it is true that the lack of sustainable efforts on the part of African institutions is partly due to poor institutional management and governance, individual level engagements between diaspora scholars and their counterparts in African host institutions remain apolitical and rarely endeavour to engage with systematic university reform. Thus, while the first and second wave diaspora engagements took it as their challenge to establish academic and political structures that would elevate higher education in Africa to international standards, the third wave perceives the poor quality of infrastructure in African universities as a challenge that limits the degree and quality of their engagement (AU/ Carleton University and Carnegie Corporation of New York, 20I9). First generation universities in Africa with better infrastructure than more recently established institutions often receive more support from African academic diaspora engagement programmes (AU/Carleton University and Carnegie Corporation of New York, 20I9).

In terms of support networks, unlike the first and second waves of academic diaspora engagement, the third wave has been made possible by international and national support networks. These may have little to do with existing national policies but with international ones relating to efforts by international organisations to support capacity building in developing countries. For example, emanating from the I962 UNESCO Conference in Madagascar on staffing and financing higher education in Africa, commitments were made by organisations from the former colonial powers, and US foundations, to support capacity building efforts in African higher education. Scholarships were awarded to African students to pursue higher degrees overseas, accompanied by funded schemes to ensure a higher rate of return of African academics. Between I999 and 2007, the US Fulbright Fellowship Programme sent 279 scholars of African origin from the US to African universities in 32 countries (Mihyo, 2008). The UNDP established the Transfer of Knowledge Through Expatriate Nationals (TOKTEN) in I983 with the aim of replacing expatriate workers in African countries with nationals with similar or better qualifications (Mihyo, 2008). However, similar schemes on the part of African governments and HEIs have been few and far between and unsustainable. Most have included short-term tax breaks and air tickets for returning academics that do not guarantee their long-term academic involvement in their home country.

Heavy reliance on external support as a strategy to sustain academic diaspora engagements with African institutions has limitations. It is uncertain if such support is availed at precisely the time that African institutions require it. For example, most diaspora academics who are funded to travel to African universities for short periods can only do so during their summer breaks. This also happens to be the period when most students in African universities are on vacation. The activities of the academic diaspora therefore only benefit students that are not bound to regular semesters. Furthermore, the amount of time that diaspora academics spend in African host institutions is likely to be determined by the funding available rather 
than the enormity of the tasks that need to be accomplished in the host institutions. The situation would be different were African institutions, through their governments to secure sustainable funding to target diaspora academics for specific periods of time. Engagements that are largely funded by external partners are also likely to lead to unsustainable relationships of dependency.

The third driver of the nature and quality of the African academic diaspora's engagements with scholars and academic institutions in Africa is the internationalisation policies of sending institutions. While such policies are portrayed as altruistic and focused on developing equal, mutually beneficial partnerships with African universities, the process remains ideologically driven and its benefits to African universities are subject to debate (International Association of Universities (IAU), 20I2; Zeleza, 20I2; Upenyu and Susanne, 2020). While internationalisation policies focus on supporting research collaboration and enhance research infrastructure in African universities (Maassen, 2020), these objectives are unlikely to be fully realised if African diaspora academics coming to African institutions are motivated more by the internationalisation policy imperatives of the sending institutions than the needs of African universities. This privilege the needs of the former over those of the latter. An African diaspora academic hosted in an African institution will, for example, have to contend with rising demands for decolonisation and Africanisation of the curriculum in African institutions while the ideological driving force for such engagement from the sending institutions' perspective is to reinforce the dominance of Eurocentric perspectives in curriculum design and delivery. Once they constitute the diaspora, African academics are associated with the scientific community of their host countries, possibly including the ideological perspectives of such communities, and are imbued with the norms and values of those academic communities (Altbach, I989). While they emerge as a force of the new higher education internationalism (Altbach, I989), such internationalism is often onesided and may not accommodate the passion for decolonisation of higher education emanating from Africa. Rather, the engagement may reinforce prevailing academic structures and hierarchies. For example, the 2OIO study on alumni and the diaspora's contribution to the Joint AfricaEU Strategy (SOFRECO, 20I0) was undertaken during a period when the extension of the 'Bologna process' to Africa was being contested by African academics (Charlier and Croché, 20I2). One would therefore argue that the study was not singularly focused on designing strategies for the European Union to better support the African diaspora to engage but was part of an exploratory study on how such engagements, if supported would facilitate the extension of the Bologna process to African higher education.
Analysing the third wave of the African academic diaspora's engagement in the context of internationalisation raises the question of what vision for and of higher education this diaspora seeks to realise in Africa. Undertaking this project in an ideologically blind manner based on notions of capacity building without questioning whose capacity is being built and whose is being eroded in Africa, would only deepen the crisis of higher education on the continent. This is not to say that the African academic diaspora is not aware of such power dynamics. Over the years, such academics have demonstrated consciousness of such conditions and have often worked to subvert the neo-colonial knowledge project in the global South, despite African institutions' limitations (Nesbit, 2003; Zeleza, 2005, 20I3). However, some studies suggest that the African academic diaspora, that works within the constrained policies of sending institutions, and in the context of North-South knowledge networks has become central to the creation of global knowledge networks that promote the interests of their (sending) universities. These institutions are seeking to expand their research remits in the context of increasingly resource constrained environments, international and national funding bodies that are increasingly focused on research relating to 'grand challenges', and the aspirations of individual researchers for whom global networks are increasingly important to successful careers (Larner, 20I4). Hence, while it is true that the African academic diaspora has become an important player in global knowledge networks, there is no clarity on which side it plays for.

The final driver of the nature and quality of the African academic diaspora's engagements with scholars and academic institutions in Africa is the incentive structure at both the national and institutional levels. At national level, the incentive structure remains the nature of politics and institutional leadership in Africa. The constitution of the African diaspora, in both its historical and contemporary sense, has been a consequence of the failure of political and higher education institutional leadership on the continent. Whether seen in terms of the historical diaspora of slavery, the immediate post-independence diaspora borne of political intolerance on the part of the leadership or on-going emigration borne of the failure of economic and educational institutions, politics explains the nature of the constitution and subsequent responses of African diaspora communities to their continent. These present two challenges. In seeking to engage with African institutions, the diaspora would opt to remain apolitical, leaving intact the political dysfunction at the national and institutional levels that created the diaspora in the first place. On the other hand, the diaspora would build strategies that go beyond academic engagement to include national and institutional governance reform. In other words, the kind of political architecture on the continent that can allow for fruitful diaspora 
engagement in the long term should be a priority for African diaspora academics, beyond academic engagement.

While several countries have designed diaspora policies and/or established diaspora desks at their Ministries of Foreign Affairs, these initiatives fall far short of creating the right incentives for diaspora engagement, especially in higher education. Firstly, a review of some country level diaspora policies reveals a redefinition of country level engagements of the diaspora to mean 'citizens' of a particular country, whereas the AU Commission sees the African diaspora as one community of 'all people of African origin' living outside the continent irrespective of citizenship, nationality and historical constitution. The country level focus is likely to limit circulation of the totality of the African academic diaspora, including the historical diaspora, in engaging. It also means that were an incentive structure to be designed, it would focus on attracting citizens of a particular country. In the recent past, the itineraries of many African heads of states travelling overseas have included meeting the country's citizens, especially academics in the diaspora, only for the diaspora to turn out to be a group of academics from the president's ethnic group. Instances where the diaspora, including the academic diaspora, mobilises along narrow ethnic or national level nationalisms may reproduce the dysfunctional nature of ethnic states which in the first instance contributed to the emergence of the diaspora (Elise and Bruno, 2019).

The second issue relates to the focus of county level 'excitement' with the diaspora. In several countries, the focus has been monetary remittances and setting up schemes through which the diaspora would be enabled to establish businesses in their countries of origin or elsewhere on the continent. Rarely have incentives focused on attracting the diaspora to engage in the higher education sector. While the African political leadership has an appetite for the diaspora's economic remittances and potential investment, it pays little attention to recouping 'intellectual remittances' from the diaspora, the values that fuel democratic institutions and accountable political systems, especially when this relates to enabling the diaspora to participate in political processes. Even when dual citizenship has been legislated, allowing the diaspora to vote or have a political voice remains a no-go territory in several countries. In a few countries, the same parliaments that have legislated dual citizenship have at the same time tried to pass parallel laws that bar diaspora citizens from serving in the public service of their countries, including being appointed to management positions in HEIs. It is important for the academic diaspora to engage in the politics of changing the institutional and academic leadership of African universities. Like African politicians, there are instances where the leadership of African universities has made it difficult for diaspora academics to undertake academic activities. The reasons for such resistance have to do with fear of the diaspora influencing change in the culture of leadership which, unfortunately, has contributed to the collapse of a quality academic culture and infrastructure in a number of African institutions. As in national politics, the impact of the academic interventions undertaken by the academic diaspora in several universities across the continent is unlikely to be maximised in the context of weak institutional and academic programme leadership. Beyond the short-term interventions that are currently being promoted, senior African diaspora academics who have been exposed to sound institutional and academic programme leadership positions could serve as vice-chancellors, deans and heads of academic programmes or even as members of the governing councils of universities in Africa for longer periods. This will assist in reforming the institutional and academic cultures of these institutions, and also contribute to the internationalisation of academic programmes through partnerships.

The third limitation relates to legal recognition of the diasporic status of citizens of African origin outside the continent. Numerous African professionals are circulating within Africa outside their countries of birth. The diaspora within Africa connects to the diaspora beyond the continent and practical measures should be adopted to connect all diasporas.

The lack of incentives at the national and institutional levels has implications for institutions' capacity to host diaspora academics. Diaspora academics are attracted to first generation universities with better facilities. These also happen to be the institutions the academics left to join the diaspora. Existing networks therefore serve as an incentive at the institutional level to forge such engagements. However, first generation institutions may not necessarily be more deserving of such interventions than their second and third generation counterparts.

\section{Conclusion}

The difference between the first, second and third waves of academic diaspora engagements is that whereas the first and second waves contributed to establishing higher education institutions where none existed and conditions at the nascent institutions left much to be desired, third wave diaspora engagements seem to be constrained by the lack of adequate incentives on the part of African institutions. A lack of infrastructure for teaching and research have been cited in the literature as limiting engagement and academic collaboration between the diaspora and their colleagues at African universities. However, African countries and universities are of the view that the diaspora can access resources that could help to alleviate some of these challenges. Furthermore, the third wave of academic diaspora engagements is taking place in a context of ideological tension between the 
forces of globalisation and internationalisation, and those of decolonisation and Africanisation.

\section{References}

African Union/Carleton University, Centre for African Studies/Carnegie Corporation of New York. (20I9). Continental Forum on the Role of the Diaspora in Higher Education, Research and Innovation in Africa. Conference Report. Addis Ababa, Ethiopia, November I3-I4.

Austin, D. (2010). Pan-Africanism, Caribbean exile, and post-colonial Africa. LLDRL Working Paper Series, WP\#I.

Bly, V.M. (I985). Walter Rodney and Africa. Journal of Black Studies 16(2, II5-I3O.

Burton, E. (2020). Decolonization, the Cold War, and African's routes to higher education overseas, I957-65. Journal of Global History 15, I69I9I.

Campbell, H. (I99I). The impact of Walter Rodney and progressive scholars on the Dar es Salaam school. Social and Economic Studies 40(2, 99-I35.

Charlier Jean-Émile, and Croché Sarah (20I2). "The Normative Influence of the Bologna Process on Francophone Universities in Africa", Education et sociétés 29, 87-I02. DOI: I0.39I7/es.029.0087. URL: https:// www.cairn.info/journal-education-et-societes-20I2-I-page-87.htm

Dell, Sharon. (2020). Tapping into the diaspora - The search for sustainability. University World News. https://www.universityworldnews. com/post.php?story=202002I30724234I2

Élise, F., and Bruno, L. (20I9). Diasporas and conflicts - understanding the nexus. Diaspora Studies 12(I), 34-5I. DOI: I0.I080/09739572 .20I8 .1538687

Ferede, M.K (n.d.). Engaging the Diaspora: Potential for sub-Saharan African Universities. Policy Brief. Programme on Innovation, Higher Education and Research for Development (IHERD).

Frenkel, M.Y.U. (I974). Edward Blyden and the Concept of African Personality. African Affairs 73(292), 277-289

Hayford, J.E.C. (1969) Ethiopia Unbound: Studies in Race Emancipation. London: Frank Cass.

Heilbron, J., and Gingras, Y. (20I8). The Globalisation of European Research in the Social Sciences and Humanities (I980-20I4). A bibliometric Study. In: Johan Heilbron, Gustavo Sor'a, and Thibaud Boncourt (eds.) The Social and Human Sciences in Global Power Relations, pp. 29-58. Palgrave Macmillan.

International Association of Universities (IAU). (20I2). Affirming Academic Value in Internationalization of Higher Education: A Call for Action.

Maassen, P. (2020). Developing equal, mutually beneficial partnerships with African universities. Recommendations for a new European col- laboration strategy (The Guild Insight Paper No. I). Retrieved from The Guild of European Research-Intensive Universities' website: https://www.the-guild.eu/publications/insight-paper-one

Marah, J.K. (I987). Educational Adaptation and Pan-Africanism: Dev-elopmental Trends in Africa. Journal of Black Studies 17(4), 460-48I.

Mihyo, P.B. (2008). Staff Retention in African Universities and Links with Diaspora Study. Association for the Development of Education in Africa (ADEA)

Mkandawire, T. (200I). Thinking about developmental states in Africa. Cambridge Journal of Economics 25(3), 289-313.

Nesbitt, F.N. (2002). African Intellectuals in the Belly of the Beast; Migration, identity and the politics of Exile. African Issues 30(I), 70-75.

Nwauwa Appollos, O. (I993). The British Establishment of Universities in Tropical Africa, I920-I948: A Reaction against the Spread of American " Radical " Influence. Cahiers d'études africaines 33(130), 247-274; doi : https://doi.org/10.3406/cea.I993.1520

Oanda, I. (2013). Trends in Internationalisation of Higher Education and Implications for Research and Innovation for Development in African Universities. In: The Development of Higher Education in Africa; Prospects and Challenges, pp. 69-97. UK: Emerald Group Publishing, Howard House.

Ogot, B.A (20II). African Historiography: From colonial historiography to UNESCO's general history of Africa. Author.

Ong'ayo, A.O. (20I4). Diaspora Engagement in a Constricted Political Space; The Case of Ethiopian Diaspora Organisations in the Netherlands. European Centre for Development Policy Management. Discussion Paper No. I68.

Shepperson, George, and Drake, St. Clare. (2008). The Fifth Pan-African Conference, I945 and the All African People's Congress, I958. Contributions in Black Studies 8, Article 5.

Sherman, M.A.B. (I990). The University in Modern Africa; towards the twenty-first Century. The Journal of Higher Education 61(4), 363-385.

SOFRECO. (2020). Study on the contribution of Alumni and Diaspora to the Joint Africa-EU Strategy. Final Report. European Union.

UNESCO. (I962). The Development of Higher Education in Africa. Report of the Conference on the Development of Higher Education in Africa, Tananarive, 3-12 September I962. UNESCO.

Upenyu, S. M., and Susanne B. R. (2020). Colonial legacies in internationalisation of higher education: racial justice and geopolitical redress in South Africa and Brazil, Compare: A Journal of Comparative and International Education 50(4), 463-48I. DOI: I0.I080/03057925 .2018 .1521264 
Zeleza, P.T. (2012a). Internationalisation in Higher Education; Opportunities and Challenges for the knowledge project in the Global South. Keynote address, Vice-Chancellors Leadership Dialogue, a SARUA leadership Dialogue on building the capacity of higher education to enhance regional development, Maputo, March 2I-22.

Zeleza, P.T. (20I2b). Engagements between African Diaspora Academics in the U.S. and Canada and African Institutions of Higher Education: Perspectives from North America and Africa. Report for Carnegie Corporation of New York.

Zeleza, P.T. (2009). The African Renaissance and Challenges of Development in the $2 \mathrm{I}^{\text {st }}$ Century. Comparative Studies of South Asia, Africa and Middle East 29(2), I55-170.

Zeleza, P.T. (2005). The Academic Diaspora and Knowledge Production in and on Africa: what Role for CODESRIA?" In: Thandika Mkandawire (ed.) African Intellectuals: Rethinking Politics, Language, Gender and Development, pp. 209-234. Dakar and London: CODESRIA Books and Zed Books. 